\title{
Animal Magnetism, Psychiatry and Subjective Experience in Nineteenth-Century Germany: Friedrich Krauß and his Nothschrei
}

\author{
BURKHART BRÜCKNER * \\ Hochschule Niederrhein University of Applied Sciences, \\ Faculty of Applied Social Sciences, Richard-Wagner-Straße 101, \\ D-41065 Mönchengladbach, Germany
}

\begin{abstract}
Friedrich Krauß (1791-1868) is the author of Nothschrei eines Magnetisch-Vergifteten [Cry of Distress by a Victim of Magnetic Poisoning] (1852), which has been considered one of the most comprehensive self-narratives of madness published in the German language. In this 1018-page work Krauß documents his acute fears of 'mesmerist' influence and persecution, his detainment in an Antwerp asylum and his encounter with various illustrious physicians across Europe. Though in many ways comparable to other prominent nineteenth-century first-person accounts (eg. John Thomas Perceval's 1838 Narrative of the Treatment Experienced by a Gentleman or Daniel Paul Schreber's 1903 Memoirs of my Nervous Illness), Krauß's story has received comparatively little scholarly attention. This is especially the case in the English-speaking world. In this article I reconstruct Krauß's biography by emphasising his relationship with physicians and his under-explored stay at the asylum. I then investigate the ways in which Krauß appropriated nascent theories about 'animal magnetism' to cope with his disturbing experiences. Finally, I address Krauß's recently discovered calligraphic oeuvre, which bears traces of his typical fears all the while showcasing his artistic skills. By moving away from the predominantly clinical perspective that has characterised earlier studies, this article reveals how Friedrich Krauß sought to make sense of his experience by selectively appropriating both orthodox and non-orthodox forms of medical knowledge. In so doing, it highlights the mutual interaction of discourses 'from above' and 'from below' as well as the influence of broader cultural forces on conceptions of self and illness during that seminal period.
\end{abstract}

Keywords: Friedrich Krauß, History of psychiatry, 19th century, Animal magnetism, Self-narrative, Germany

* Richard-Wagner-Str. 101, D-41065 Mönchengladbach, Germany. Email address for correspondence: burkhart.brueckner@hs-niederrhein.de

I would like to thank the editors of this special issue and the anonymous referees for helpful feedback and comments on earlier versions of this paper. 


\section{Introduction}

In 1852, Friedrich Krauß, a travelling salesman from Southern Germany, published a massive volume with the lurid title Nothschrei eines Magnetisch-Vergifteten [Cry of Distress by a Victim of Magnetic Poisoning] in which he accused a Flemish family of trying to assassinate him. He claimed that for thirty-six years, this family had been attacking and 'smouldering' him daily with electromagnetic gases; that the perpetrators were everywhere, talked to him, read his mind and invaded his dreams. Krauß maintained that despite numerous calls for help to the authorities, the police, lawyers and doctors all over Europe, nobody had come to his rescue. He saw this publication as his last resort, 'not as a matter of free choice but as a cry of distress evoked by the most disgraceful misery'. ${ }^{1}$

The volume is a thorny 1018-page compilation of explanations, petitions, letters and notes. Convinced that he had been the victim of mesmerist forces since 1816, Krauß kept record of his consultations with numerous prominent physicians. He also published a follow-up volume to Nothschrei in 1867 , one year before his death. ${ }^{2}$ It was not until 1967 that his writings were rediscovered and re-interpreted as a significant first-person account of 'schizophrenia' - even though Krauß never saw himself as being 'mentally ill'. ${ }^{3}$ Since then, the full extent of his productivity has come to light: we now know that Krauß authored six publications, comprising about 1500 printed pages altogether, which include two portfolios of calligraphies compiled in 1822 and 1849.

This article presents the current state of research on this little-known case from a historical and a historiographical perspective. Following some biographical details on Krauß, I investigate the development of Mesmerism in early nineteenth-century Germany and show Krauß's complex appropriation of this knowledge. I then analyse his specific way of dealing with his suffering, before highlighting the significance of this narrative for patient-centred historiography. As the case of a layman who contacted some of the most prominent physicians of his time, Friedrich Krauß's story helps us better understand not only the diffusion of various forms of knowledge, but also the ways in which views 'from below' and theories 'from above' interacted during this seminal period.

\footnotetext{
${ }^{1}$ Friedrich Krauß, Nothschrei eines Magnetisch-Vergifteten; Thatbestand, erklärt durch ungeschminkte Beschreibung des 36jährigen Hergangs, belegt mit allen Beweisen und Zeugnissen. Zur Belehrung und Warnung besonders für Familienväter und Geschäftsleute (Stuttgart: author's edition, 1852), VN 21. Copies of this book are very rare and exist in six libraries: the Staatsbibliothek zu Berlin, the Universitätsbibliothek Heidelberg, the Bibliothek der Akademie der Naturforscher Leopoldina (Halle), the Universitätsbibliothek Tübingen, the Cambridge University Library (Society for Psychical Research), and the US National Library of Medicine. Some copies additionally have an illustrated 1853 title page and a brief postscript. All quotations are taken from the Berlin copy and translated by the author. The volume is not uniformly paginated; for the first pagination (pp. 4-91), I use the initials VN, cf. Torsten Hahn, Jutta Person and Nicolas Pethes (eds), Grenzgänge zwischen Wahn und Wissen: Zur Koevolution von Experiment und Paranoia 1850-1910 (Frankfurt am Main: Campus, 2002), 36. My special thanks go to Andrea Toenjes for her advice on the translation of Krauß's texts.

${ }^{2}$ Friedrich Krauß, Nothgedrungene Fortsetzung meines Nothschrei gegen meine Vergiftung mit concentrirtem Lebensäther und gründliche Erklärung der maskirten Einwirkungsweise desselben auf Geist und Körper zum Scheinleben (Stuttgart: author's edition, 1867). There are four copies of the book: in the Staatsbibliothek zu Berlin, in the Universitätsbibliothek Göttingen, in the Cambridge University Library, and in the US National Library of Medicine.

${ }^{3}$ Heinz Ahlenstiel and Joachim Ernst Meyer (eds), Nothschrei eines Magnetisch-Vergifteten: Selbstschilderungen eines Geisteskranken (Leverkusen: Bayer, 1967).
} 


\section{Patient-Centred Historiography as a Historiography of Experience}

In 1985, Roy Porter exhorted historians to put more emphasis on patient-centred accounts within the social history of medicine. ${ }^{4}$ Looking at medical treatment from a user perspective, researchers have heard his call by focusing on the patients' experiences and views, as well as their attitudes towards experts rather than merely the other way around. In his 1987 classic, A Social History of Madness, Porter wrote:

Instead of principally reading between the lines, searching out hidden meanings, reconstructing lost childhoods, baring unspoken desires, I wish to explore what mad people meant to say, what was on their minds. Their testimonies are eloquent of their hopes and fears, the injustices they suffered, above all of what it was like to be mad or to be thought to be mad. ${ }^{5}$

This approach of writing history 'from below' integrates both patient documents such as autobiographies, letters and diaries, and official documents, such as medical files and photographs. ${ }^{6}$ Social historians of psychiatry in the past thirty years have moved beyond this strict patient-doctor dyad to also include a plethora of previously neglected actors: nursing staff, outpatients and family members. ${ }^{7}$ Yet analyses of first-person narratives that critically explore the relationship between individual subjectivities and broader sociocultural networks remain relatively rare. ${ }^{8}$

The history of first-person accounts of madness can be traced back to ancient times. ${ }^{9}$ In Europe, three subforms of this genre had developed by the late Enlightenment: protests against the conditions of treatment, autobiographical narratives, and scholarly self-reflections. ${ }^{10}$ In German-speaking regions specifically, the number of published firstperson accounts increased significantly during the nineteenth century. ${ }^{11}$ Several of the more prominent cases are related to phenomena such as mind control or influencing machines, witness for example the story of James Tilly Matthews (1770-1815) and his technical phantasms in Bethlem Hospital circa 1804, ${ }^{12}$ August Strindberg (1849-1912)

\footnotetext{
${ }^{4}$ Roy Porter, 'The Patient's View: Doing Medical History from Below', Theory and Society, 14, 2 (1985), 175-98.

${ }^{5}$ Roy Porter, A Social History of Madness: The World Through the Eyes of the Insane (New York: Weidenfeld \& Nicolson, 1988), 1.

${ }^{6}$ On types of sources and the autobiographical subject, see Kaspar von Greyerz, 'Ego-Documents: The Last Word?', German History, 28, 3 (2010), 273-82. On working with medical files, see Geoffrey Reaume, Remembrance of Patients Past: Patient Life at the Toronto Hospital for the Insane, 1870-1940 (New York: Oxford University Press, 2000).

${ }^{7}$ See, eg., Akihito Suzuki, Madness at Home: The Psychiatrist, the Patient and the Family in England, 1820 60 (Berkeley, CA: University of California Press, 2006); Hilary Marland, Dangerous Motherhood: Insanity and Childbirth in Victorian Britain (Basingstoke and New York: Palgrave Macmillan, 2004).

${ }^{8}$ Roy Porter's Social History of Madness, op. cit. (note 5) mainly presents prominent cases; see Alexandra Bacopoulos-Viau and Aude Fauvel, 'The Patient's Turn' (in this issue). See also, Monika Ankele, Alltag und Aneignung in Psychiatrien um 1900: Selbstzeugnisse von Frauen aus der Sammlung Prinzhorn (Cologne: Böhlau, 2009); Gail A. Hornstein, Agnes's Jacket: A Psychologist's Search for the Meanings of Madness (New York: Rodale, 2009); Philipp Osten (ed.), Patientendokumente: Krankheit in Selbstzeugnissen (Stuttgart: Steiner 2010).

${ }^{9}$ Burkhart Brückner, Delirium und Wahn: Geschichte, Selbstzeugnisse und Theorien von der Antike bis 1900, Vol. 1, Vom Altertum bis zur Aufklärung (Hürtgenwald: Pressler, 2007).

${ }^{10}$ Ibid., 473-90.

11 Burkhart Brückner, Delirium und Wahn: Geschichte, Selbstzeugnisse und Theorien von der Antike bis 1900, Vol. 2, 19. Jahrhundert: Deutschland (Hürtgenwald: Pressler, 2007), 132-283, inc. an index of the personal narratives examined, 301-10; on Krauß, see 236-57.

12 James Tilly Matthews, untitled chapter in John Haslam, Illustrations of Madness (London: Hayden, 1810), $42-51,59-79$.
} 
and his 'Inferno crisis' circa $1895,{ }^{13}$ and Daniel Paul Schreber (1842-1911), who famously described his hypnotic relationship with his psychiatrist Paul Flechsig in his 1903 book Denkwürdigkeiten eines Nervenkranken [Memoirs of My Nervous Illness]. ${ }^{14}$ The work of Friedrich Krauß, though lesser known, certainly belongs in this list.

Research using sources of this type always raises the question, 'Who talks about the personal narratives, the authors and their experiences - and in which way?' 15 As Michel Foucault noted in 1976:

Everyone dreams of writing a history of the mad, of going over to the other side and tracing the great evasions of the subtle retreats into delirium from the beginning. Yet, under the pretext of tuning in and letting the mad themselves speak, one already accepts the division between the two as a fact. It's necessarily better to put oneself at the point where the machinery that makes these qualifications and disqualifications is actually operative, and putting the mad and the non-mad on two sides facing each other. ${ }^{16}$

Working with personal narratives thus requires a critical appraisal of their content in order to determine a viable reference point for the selection of suitable texts. ${ }^{17}$ The starting point is to analyse the authors' subjective experiences by taking into account the sociocultural conditions in which they occurred, and asking how these experiences related to contemporaneous modes of knowledge-making and interpretation. This concept of a patient-centred history that is both interpretive and subject-oriented - as applied in this article - represents an attempt to overcome the dilemma between ahistorical presentism on the one hand, and contextualist relativism on the other. It also offers a fuller picture of the multidimensionality involved in patient care.

\section{The Life of Friedrich Krauß}

Friedrich Krauß's Nothschrei covers the life of a German man during the first half of the nineteenth century, spanning the years from the Napoleonic era to the postrevolutionary era of the 1850 s. The subsequent volume, Fortsetzung, ends shortly before the foundation of the German Empire in 1871. Krauß therefore witnessed the revolutionary transformation of the small German states from estate societies to constitutional and, later, industrialised societies. Raised in the Duchy of Württemberg, the heartland of the Kingdom of Württemberg (founded in 1806 and a predominantly agrarian region in southwest Germany marked by rural poverty), he later spent many years in Heidelberg in the Grand Duchy of Baden (a hotspot of political liberalism in the years prior to the 1848 March Revolution). ${ }^{18}$ Throughout his life Krauß witnessed significant changes in medical theories related to so-called animal magnetism, and in turn selectively appropriated them for his own purposes. By narrating his encounter with various physicians and his experience in an early nineteenth-century private asylum, Krauß's case

13 August Strindberg, Inferno / From an Occult Diary, trans. Mary Sandbach, ed. Thorsten Eklund (London: Penguin, 1979) [first published in 1897].

14 Daniel Paul Schreber, Denkwürdigkeiten eines Nervenkranken (Leipzig: Mutze, 1903; Wiesbaden: focus, 1973), 7.

${ }^{15}$ On authenticity and ethics, see Marian Barnes and Phil Cotterell (eds), Critical Perspectives on User Involvement (Bristol: Policy Press, 2012).

16 Michel Foucault, 'Sorcery and madness', in Sylvėre Lotringer (ed.), Foucault Live (Collected Interviews, 1966-84) (New York: Semiotext(e), 1989), 201.

17 On the methodology applied, see Brückner, op. cit. (note 11), 178-86. On the identity of the research-object in a historical perspective, see Flurin Condrau, 'The Patient's View Meets the Clinical Gaze', Social History of Medicine, 20, 3 (2007), 525-40.

${ }^{18}$ Hansmartin Schwarzmaier and Meinrad Schaab (eds), Handbuch der Baden-Württembergischen Geschichte, Vol. 3 (Stuttgart: Clett-Kotta, 1992), 84 ff. 
sheds light on the scientific and extra-scientific diffusion of knowledge about 'madness' at that period.

Krauß was born on 19 March 1791 in the small town of Göppingen. Together with his two sisters, he grew up in a Protestant family of tawers. Not much is known about his background except that his grandfather was a civil servant in the town administration and that his father died early. In the evenings the young boy used to pray with his grandmother (1710-1808). ${ }^{19}$ He showed a gift for languages and, true to his motto 'a lazy youth, a lousy age', the fifteen-year-old Krauß devoted himself to the 'dry study of grammar and arithmetic books'. At the age of seventeen, he found a post as a foreign language correspondent in Strasbourg, about $100 \mathrm{~km}$ from his home, where he stayed for two years. He moved to Paris in 1812. Of his years as an apprentice, Krauß would later write that he was a 'lively character ... receiving too harsh a treatment'. He thus felt rather low-spirited when he arrived in Antwerp in 1814 to join the trading firm Daniël Thuret \& Comp. as a chancery clerk. ${ }^{20}$

Around the year 1800, Antwerp had about 50000 inhabitants, $22 \%$ of which were immigrants. Following the decline of the textile industry, the city went through a period of economic crisis but eventually developed into a major seaport by $1840 .^{21}$ Krauß's employer, Daniël Thuret, was a maritime trader. ${ }^{22}$ After being promoted to senior chancery clerk, Krauß wrote 'thirty to forty business letters per day. ${ }^{23} \mathrm{He}$ described himself as a competent, down-to-earth man with 'silvery blonde' hair and a robust physique, ${ }^{24}$ who was 'not given to sentimentality' and was appreciated by his employers as an honest, Christian man. ${ }^{25}$

In the autumn of 1814 , at age 23, Krauß suffered a severe crisis in which he started imagining himself entangled in a strange affair with a neighbour's daughter. The lady in question - who was around his age and came from the wealthy Jewish van Asten family had purportedly tried to 'magnetise [him] several times with her eyes' through the window of her house. In his Nothschrei, Krauß claimed that he found her ugly and sternly rejected her advances:

I was too independent to give myself away in such a way as a rude thing's sweetheart; too ignoble a role for a man with self-esteem, too loathsome a bondage for me, which this brute would have pent up to the deepest disgust by her dirty triteness and repugnant wickedness of character. ${ }^{26}$

Krauß held a secure professional position and might have considered starting a family, but the young woman who allegedly made advances on him was of a higher social standing and probably beyond his reach. ${ }^{27}$ In any case he felt ill at ease, became irritable and quarrelsome at work, and developed symptoms of anxiety.

${ }^{19} \mathrm{Krau}$, op. cit. (note 1), 230.

${ }^{20}$ Ibid., 258.

21 See Anne Winter, Migrants and Urban Change: Newcomers to Antwerp, 1760-1860 (London: Pickering and Chatto, 2009).

22 Daniël Thuret (1778-1852) was ranked the 62nd richest man in Antwerp in 1814. He was married to Françoise Marie Guyot; see Gladys Guyot, 'Le Patronyme Guyot et la famille Guyot, d'Anvers (fin)', L'Intermédiaire des généalogistes, 207, 3 (1980), 168-96. My thanks go to Hilde Greefs for providing this information.

${ }^{23} \mathrm{Krau}$, op. cit. (note 1), 258.

${ }^{24}$ Ibid., 200, 138, 186.

${ }^{25}$ Ibid., VN 18, 175, 199.

${ }^{26}$ Ibid., 200, cf. 115 f.

${ }^{27}$ Ibid., 262, 545. 
The first ideas of persecution emerged soon thereafter. Krauß began to imagine his workmates whispering things behind his back and he eventually heard voices calling him a 'fool' and a 'madman' ${ }^{28} \mathrm{He}$ also became convinced that at some point the van Asten father had intervened using 'magnetic influencing' to deter his daughter from pursuing him. ${ }^{29}$ Further involved in this conspiracy, he believed, were a 'magnetiser' from Strasbourg and a junior copyist at the office (who was also the employer's nephew), the latter of whom was purportedly courting the van Astens' daughter. According to his Nothschrei, Krauß tried hard to avoid the allegedly hostile van Asten family. Nevertheless, in 1815 he fell into 'an inexplicable, hitherto unknown state', and became ill and suicidal. ${ }^{30}$ Although his employer offered a salary increase, he fled to London - only to realise with horror that the van Asten family was haunting him even there. Back in Antwerp and with a new job in bookselling, six sleepless weeks purportedly rendered him unable to work. ${ }^{31}$ In August 1816, Krauß consulted three doctors who, as he wrote, 'unanimously' diagnosed him with 'magnetisation'. He went on to remark, 'it was only then that I finally understood my condition, as I had never before heard about animal magnetism. . , 32

This revelation might explain why Krauß became even more outraged with his 'enemies' and their alleged doings. In October 1816, he met his employer's nephew in the street, challenged him to a duel and attacked him. ${ }^{33}$ The police intervened. 'Without any interrogation', Krauß claimed, he was taken to the 'Cellite convent'. This small institution, run by the Alexian Brothers, was most likely a private madhouse in the tradition of the Dutch beterhuizen [houses of correction]. ${ }^{34}$ Krauß was told that he was committed by 'mayoral order'. ${ }^{35}$ He reported that he was beaten and, a few days later, was examined by the 'magnetisers' own doctors, 'Houlaers and van der Zanden', who diagnosed him with 'pure imagination' and prescribed a treatment consisting of 'cold baths' ${ }^{36} \mathrm{Krau}$ felt exposed to all of his enemies, who subjected him to a 'general examination' lasting 'forty horrible nights'. He could nevertheless receive visitors, gifts and letters. An escape attempt in 1817 failed. ${ }^{37}$ After ten months, he was transferred to an 'even more terrible prison' for 'further investigation into the [violent] events'. Confined in a small cell, he repeatedly tried to 'smash [his] head' on the wall. Later developments are unknown. Krauß was in any case released after eighteen months and subsequently claimed that he had to pay 800 guilders for living expenses. ${ }^{38}$

In Antwerp, as in many other European cities, therapeutic asylums were still in their early stages. In 1825 the reformer Édouard Ducpétiaux (1804-1868) listed thirty institutions with 5591 patients in the territory that later became Belgium. He

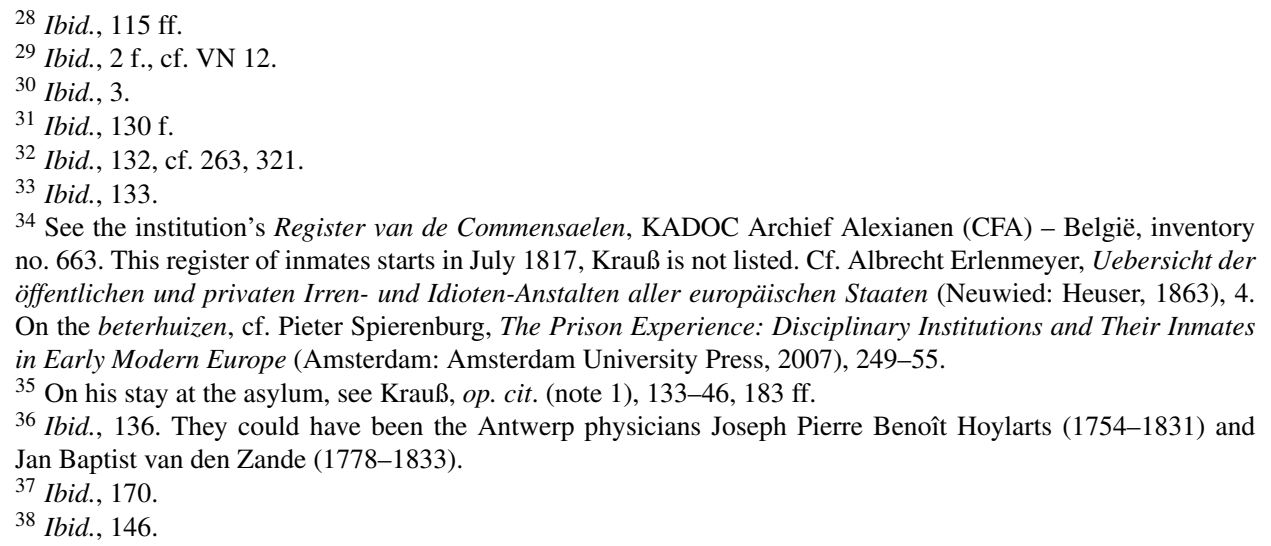


criticised these establishments' prison-like conditions, high mortality rates and arbitrary committals. ${ }^{39}$ From 1815 onwards, institutionalisation could simply be ordered by the local authorities, as was the case with Krauß. Medical assessment was required but no court order needed. It was not until 1841 that Belgium adopted legal provisions following the example of France's 1838 statute on the rights of mentally ill individuals [loi des aliénés].

Krauß later noted about this event:

I thought about going to Antwerp, but refrained from doing so since I would have been exposed to the same outrageous maltreatment as in $1816 \ldots$ for all complaints of hardship and all hopes are silenced in the madhouse. ${ }^{40}$

It remains unclear, however, why Krauß was not taken to the municipal asylum. ${ }^{41}$ The Alexian Brothers traditionally cared for the diseased. As stated above, Krauß was probably at their newly opened men's home on Antwerp's Jezusstraat. The 800 guilders they allegedly charged for eighteen months exceeded by fourfold the rates of the municipal asylum. ${ }^{42}$

In the spring of 1818, a doctor accompanied Krauß back to his hometown of Göppingen. His relatives were unable to help and the disturbances persisted. Later that year, Krauß asked a bookseller to print his first accusation against his tormentors. This bookseller instead referred him to the renowned physician and poet Justinus Kerner (1786-1862), a prominent advocate of mesmeric theories. ${ }^{43}$

\section{Krauß and the Popularisation of Mesmerism in Early Nineteenth-Century Germany}

It was circa 1775 that Franz Anton Mesmer (1734-1815) developed his concept of 'animal magnetism', positing the idea of a 'universal fluid' that penetrated all organisms and could be used for healing purposes. Mesmer's theories were broadly discussed in early nineteenth-century Germany, particularly under the influence of his follower, Armand Marie Jacques de Chastenet de Puységur (1751-1825), who claimed that the magnetiser's sheer willpower alone could induce an 'artificial healing sleep' (somnambulism) thought to be therapeutic. The whole concept offered a new perspective in the tradition of Neoplatonism and was adopted particularly by the followers of Schelling's Naturphilosophie. ${ }^{44}$

In 1812, King Frederick William III of Prussia appointed a commission chaired by Christoph Wilhelm Hufeland to investigate this concept of 'healing magnetism', and, in

\footnotetext{
${ }^{39}$ Édouard Ducpétiaux, Verhältnisse der Irren in Belgien und Vorschläge zur Verbesserung ihres Looses [first published in 1832] (Regensburg: Pustet, 1834), 10-17, 34.

${ }^{40} \mathrm{Krau}$, op. cit. (note 1), $528 \mathrm{f}$.

41 On Antwerp's municipal asylum, see Joseph Guislain, Traité sur l'aliénation mentale et sur les hospices des aliénés, Vol. II (Amsterdam: Hey, Gartmann, 1826), 192.

42 Cf. Ducpétiaux, op. cit. (note 39), 27.

43 On Kerner, see Otto-Joachim Grüsser, Justinus Kerner 1786-1862: Arzt - Poet - Geisterseher (Berlin: Springer, 1987); on Kerner's encounter with Krauß, see $181 \mathrm{f}$.

${ }^{44}$ Cf. Alan Gauld, A History of Hypnotism (Cambridge: Cambridge University Press, 1992), 141-62; Heinz Schott (ed.), Franz Anton Mesmer und die Geschichte des Mesmerismus (Stuttgart: Steiner, 1985); Henri Ellenberger, The Discovery of the Unconscious. The History and Evolution of Dynamic Psychiatry (New York: Basic Books, 1970). On the reception of Mesmerism in Germany, see Anneliese Ego, 'Animalischer Magnetismus', oder, 'Aufklärung': Eine mentalitätsgeschichtliche Studie zum Konflikt um ein Heilkonzept im 18. Jahrhundert (Würzburg: Königshausen + Neumann, 1991).
} 
1816, the use of this method was approved for medical purposes only. Mesmerism took root in German universities between 1809 and 1819. In Berlin, Karl Christian Wolfart (1788-1832) was appointed professor of 'pathology, therapy, mesmerism and magnetism' in 1817 , a move opposed by a number of more orthodox physicians. ${ }^{45}$ Yet various other doctors in the field of 'psychic medicine' were also interested in mesmeric theories; among them, for instance, were Joseph Ennemoser (1787-1854) and Christian Friedrich Nasse (1778-1851) in Bonn. The movement's most important journal, Archiv für den Thierischen Magnetismus [Archive of Animal Magnetism], appeared between 1817 and 1823.

Krauß wrote in his Nothschrei that he gained his knowledge of Mesmerism from the writings of Johann Heinrich Jung-Stilling (1770-1817) and Ennemoser's Geschichte des thierischen Magnetismus [History of Animal Magnetism] ${ }^{46}$ In addition, during this crucial period he was in direct contact with two prominent figures of the medical community: Justinus Kerner (1786-1862) and another renowned physician, Dietrich Georg von Kieser (1779-1862). These two doctors represented two different strands of Mesmerism: Kieser drew on Schelling's Naturphilosophie, while Kerner's later work leaned towards occultism.

In the autumn of 1818 , Krauß consulted Kerner, by then a senior medical officer, who as a student in Tübingen had cared for the poet Friedrich Hölderlin in 1806 and later became one of the most prominent physicians of the Romantic era. ${ }^{47}$ The physician documented his encounter with a certain 'Mr K.' (Krauß) in his 1824 book, Geschichte zweyer Somnambülen [History of Two Somnambulists], which included an anamnesis and two letters. ${ }^{48}$ In a brief comment he stated that Krauß seemed 'most unhappy' but 'fairly reasonable', apart from his 'idée fixe'. Yet Kerner also added that he had failed to talk him out of this 'faulty imagination' and issued him a letter of recommendation simply out of pity. Krauß, for his part, reported in Nothschrei that Kerner gave him a glass plate to make the 'magnetic rapport' go away. He also protested against Kerner's diagnosis. ${ }^{49}$

Dietrich Georg von Kieser was one of the most important advocates of Mesmerism among German physicians practising 'psychic medicine'. ${ }^{50}$ In his 1822 book, System des Tellurismus [System of Tellurism], he depicted himself as a proponent of Enlightenment ideals. According to Kieser, magnetism was the medium that unfailingly connected human beings with 'telluric' or earthly forces - and while healthy organisms were characterised

\footnotetext{
45 Siegfried Jaeger, 'Psychologierelevante Lehrende an der Berliner Universität im 19. Jahrhundert', Psychologie und Geschichte, 6, $3 / 4$ (1995), 268; for details of the controversy in Berlin, see Philipp Osten, Das Tor zur Seele: Schlaf, Somnambulismus und Hellsehen im frühen 19. Jahrhundert (Paderborn: Schöningh, 2015), 43-50.

${ }^{46} \mathrm{Krau}$, op. cit. (note 1), VN 24; cf. Johann Heinrich Jung-Stilling, Theorie der Geister-Kunde (Nuremberg: Raw, 1808).

${ }^{47}$ It was two years after his encounter with Krauß that Kerner would start treating his most illustrious patient, Friederike Hauffe (1801-1829), the so-called 'Seeress of Prevorst'; see Justinus Kerner, Die Seherin von Prevorst: Eröffnungen über das innere Leben des Menschen, und über das Hereinragen einer Geisterwelt in die unsrige, 2 vols (Stuttgart: Cotta, 1829). Hauffe had developed inexplicable convulsions, bleedings and fever after an unhappy love affair. Medication did not help and Kerner performed 'magnetic operations' during which his patient fell into states of trance and produced manifold visions and prophetic dreams. This caused a tremendous public stir. Hauffe died three years later. The case raised heated debates amongst Kerners's critics, including, for instance, Albert Zeller (1804-1877), who would become director of the Winnenthal asylum in 1833; see Albert Zeller, Das verschleierte Bild zu Sais oder die Wunder des Magnetismus (Leipzig: Weidemann 1830), 159.

48 Justinus Kerner, Geschichte zweyer Somnambülen (Karlsruhe: Braun, 1824), 420-26.

${ }^{49} \mathrm{Krau}$, op. cit. (note 1), $255 \mathrm{f}$.

${ }^{50}$ On Kieser, see Walter Brednow, 'Dietrich Georg Kieser: Sein Leben und Werk', Sudhoffs Archiv, Supplement 12 (1970). Heike Scheuerbrandt, 'Die Stimme der Natur: Dietrich Georg Kiesers Auffassung vom tierischen Magnetismus', Athenäum: Jahrbuch für Romantik 9 (1999), 227-49.
} 


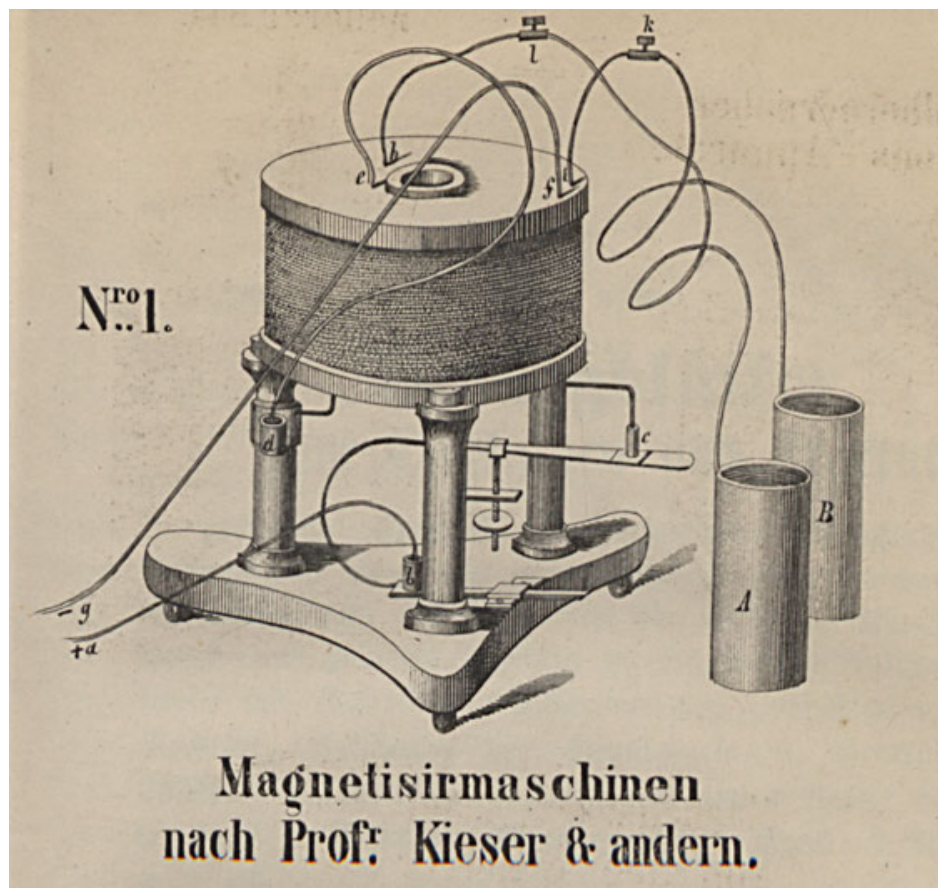

Figure 1: 'Magnetising device based on Prof. Kieser \& others'. F. Krauß, Nothschrei (1852), plate, p. 916, Staatsbibliothek zu Berlin, Preußischer Kulturbesitz (Sig. Kk 6790).

by a good balance of positive and negative forces, disease occurred when negative, immoral forces gained the upper hand. He thus believed that somnambulist phenomena, like sleepwalking, visions and convulsions, could be attributed to natural forces and cured with positive magnetic power. Kieser was further convinced that the 'magnetic rapport' between magnetiser and patient also enabled 'manipulations', such as emotional or visual clairvoyance. $^{51}$

Krauß incorporated these concepts into his writings. For example, according to Kieser the aforementioned positive magnetic powers could be transmitted using 'magnetophores' such as iron balls, mirrors and 'vats'. It was one of these vats that Krauß depicted in his Nothschrei (Figure 1). ${ }^{52}$

Krauß also claimed that he corresponded with Kieser and that he received five letters from him. These have not been found. In any case, Kieser did briefly review Nothschrei in Allgemeine Zeitschrift für Psychiatrie und psychisch-gerichtliche Medicin [General Journal for Psychiatry and Mental Forensic Medicine] two years after the book appeared in 1852. He diagnosed the author with a form of "melancholia ... with acoustic

${ }^{51}$ Dietrich Georg Kieser, System des Tellurismus oder Thierischen Magnetismus: Ein Handbuch für Naturforscher und Aerzte, 2 vols, 2nd edn (Leipzig: Herbig, 1826), Vol. 1, 7-19; Vol. 2, 170 ff., 288 ff.

52 Ibid., Vol. 1, 459. 
hallucinations' but prudently left all other conclusions up to the reader. ${ }^{53}$ This was the first time that Krauß's full name was mentioned to an expert public.

Despite their mesmerist background, both Kieser and Kerner appropriated orthodox nosological entities to make sense of Krauß's condition. In his 1824 book, Justinus Kerner concluded: 'Mr K. can probably not be cured of his idée fixe' ${ }^{54}$ The term 'idée fixe' was well established in early nineteenth-century psychiatry. In 1803, Johann Christian Reil (1759-1813) already differentiated between eleven manifestations of idées fixes associated with the clinical picture of Verrücktheit [madness]. ${ }^{55}$ In about 1830, the term was also adopted as part of Jean-Étienne Dominique Esquirol's (1772-1840) theory of monomania. The French alienist defined monomania as a 'fixed', 'partial' and 'chronic delirium without fever' induced by 'passion and excitement'. ${ }^{56}$ Both Kieser and Kerner concluded that Krauß's symptoms were chronic, partial and affective but neither dangerous nor induced by magnetism. 57

This case, then, might be cited to highlight the fact that in practice, there were actually more similarities between the different schools of thought in early German psychiatry than Johann Baptist Friedreich's (1796-1862) famous 1836 distinction between 'psychic', 'somatic' and 'moderating' approaches would have us believe. ${ }^{58}$ Framing the history of German psychiatry as a history of binary conflicts between 'Enlightenment' and 'Romanticism', 'science' and 'mysticism' or 'somatists' and 'psychicists' would therefore be as simplistic as the teleological view that Mesmerism was merely a precursor to hypnotism and psychoanalysis. ${ }^{59}$

Beyond these theoretical considerations, it is also interesting to remark upon the appropriation by Krauß of these various physicians' therapeutic practices. In $1819 \mathrm{Krau} ß$ consulted the Heidelberg professor of medicine Franz Josef Schelver (1778-1843), who prescribed rubbing iron to divert magnetic influences. '[T]his provides some relief, but who can rub and stroke all day and night?' Krauß complained in an 1822 letter to Kerner. ${ }^{60}$ The latter eventually concluded that this might have been the wrong treatment. ${ }^{61}$

A controversial figure himself, Schelver was an advocate of Schelling's Naturphilosophie, lectured on 'magnetic medicine' and ran his own practice equipped with a 'magnetic vat'

\footnotetext{
53 Dietrich Georg Kieser, review of Nothschrei, Allgemeine Zeitschrift für Psychiatrie und psychisch-gerichtliche Medicin, 11, 4 (1854), 705-6. A year earlier Kieser had already presented another, strikingly similar case: Dietrich Georg von Kieser, 'Melancholia daemonomaniaca occulta, in einem Selbstbekenntniss des Kranken geschildert', Allgemeine Zeitschrift für Psychiatrie und psychisch-gerichtliche Medicin, 10, 1 (1853), 423-57; cf. the mentioning of this case in Krauß,op. cit. (note 2), 30.

${ }^{54}$ Kerner, op. cit. (note 48), 426.

55 Johann Christian Reil, Rhapsodieen über die Anwendung der psychischen Curmethode auf Geisteszerrüttungen (Halle: Curt, 1803), 305-64.

56 Jean-Étienne Esquirol, Allgemeine und specielle Pathologie und Therapie der Seelenstörungen (Leipzig: Hartmann, 1827), 293. Cf. on the issue of monomania, Jan Goldstein, Console and Classify: The French Psychiatric Profession in the Nineteenth Century (New York: Cambridge University Press, 1987), 152-96.

57 See Dietrich Georg Kieser, Elemente der Psychiatrik (Bonn: Akademie, Weber, 1855), 301.

58 Johann Baptist Friedreich, Historisch-kritische Darstellung der Theorien über das Wesen und den Sitz der psychischen Krankheiten (Leipzig: Wigand, 1836). Cf. Michael Kutzer, “'Psychiker' als 'Somatiker': 'Somatiker' als 'Psychiker"', in Eric J. Engstrom and Volker Roelcke (eds), Psychiatrie im 19. Jahrhundert (Basel: Schwabe, 2003), 27-47.

59 The teleological view was particularly held by Ellenberger, op. cit. (note 44). In any case, the concept of a magnetic 'fluid' lost its epistemological significance over the course of the nineteenth century. By 1860 , Mesmerism no longer provided a reference of choice for the emerging psychiatric establishment.

${ }^{60}$ Friedrich Krauß, '[Letter dated 19 September 1822]', in Kerner, op. cit. (note 48), 425.

${ }^{61}$ Kerner, op. cit. (note 48), 426; Krauß, op. cit. (note 1), 255.
} 


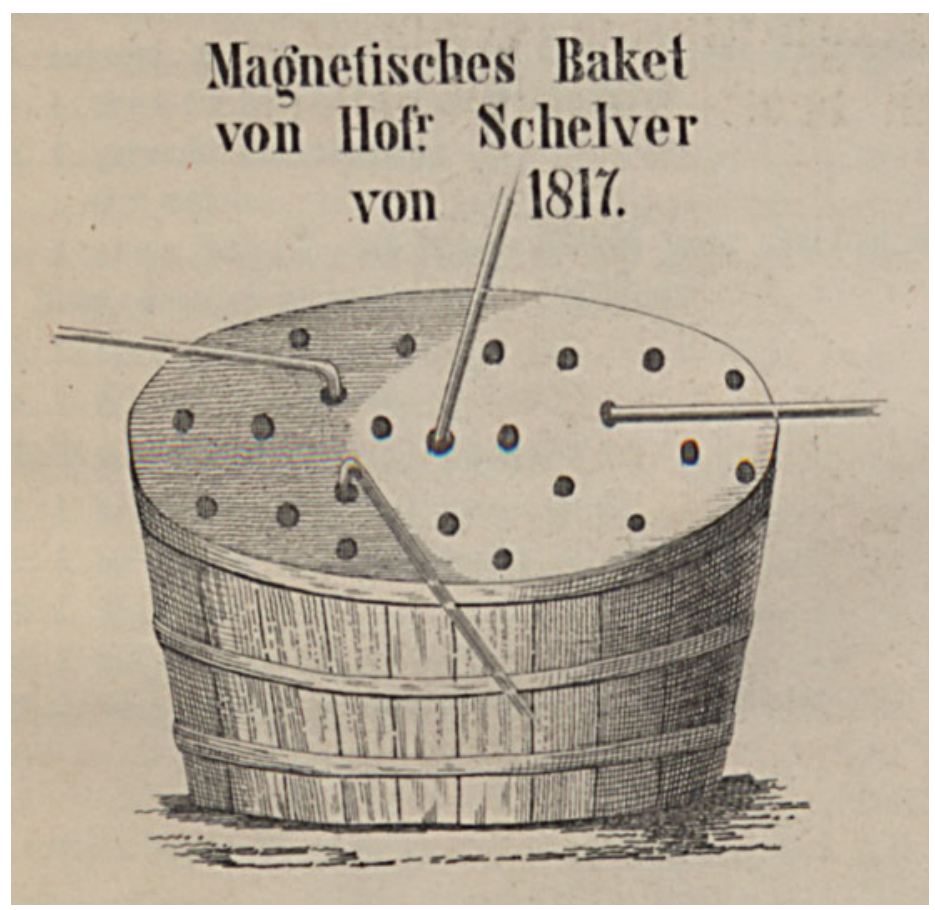

Figure 2: 'Hofrat Schelver's magnetic vat of 1817'. F. Krauß, Nothschrei (1852), plate, p. 916, Staatsbibliothek zu Berlin, Preußischer Kulturbesitz (Sig. Kk 6790).

like the one depicted in Nothschrei (Figure 2). ${ }^{62}$ Krauß reported:

Sometimes the professor [Schelver] approached the vat, around which sat several people about to be influenced, held his hands above the water, then folded them and raised his hands and gaze heavenwards as if in mystical prayer but in fact only to more strongly infuse the water with the magnetic gas, which then pervaded the sufferers. ${ }^{63}$

In addition to this treatment, Schelver prescribed a 'stomach-strengthening mixture' of nutmeg, cinnamon and cloves. He 'made great efforts' to help, and Krauß did seem to improve.

In 1819 , Krauß started to work as a teacher of languages, bookkeeping, mercantile law and technical chemistry in Heidelberg. ${ }^{64} \mathrm{He}$ also pinned his hopes on the nostalgic art of calligraphic penmanship. In 1822, he published his first portfolio of calligraphies titled Englische und Deutsche Vorschriften für Junge und Aeltere [English and German Style Sheets for the Young and Old].$^{65}$ Belonging to the genre of writing-master's books, it includes a selection of fourteen style sheets for German and English script, chancery

62 On Schelver, see Klaus-Dieter Müller, Franz Josef Schelver 1778-1832: Romantischer Naturphilosoph, Botaniker und Magnetiseur im Zeitalter Goethes (Stuttgart: Wissenschaftliche Verlagsgesellschaft, 1992).

${ }^{63} \mathrm{Krau} \beta$, op. cit. (note 1), 25, 30.

${ }^{64}$ Ibid., $23 \mathrm{ff} ., 249$.

${ }^{65}$ Friedrich Krauß, Englische und Deutsche Vorschriften für Junge und Aeltere; mit den fasslichsten Einleitungen und allen Abartungen der Buchstaben (Heidelberg, 1822). Copies exist in three libraries: the Staatsbibliothek zu Berlin $(32 \times 24 \mathrm{~cm})$, the Ernst-August-Bibliothek (Wolfenbüttel), and the Getty Research Institute Library (Los Angeles). 


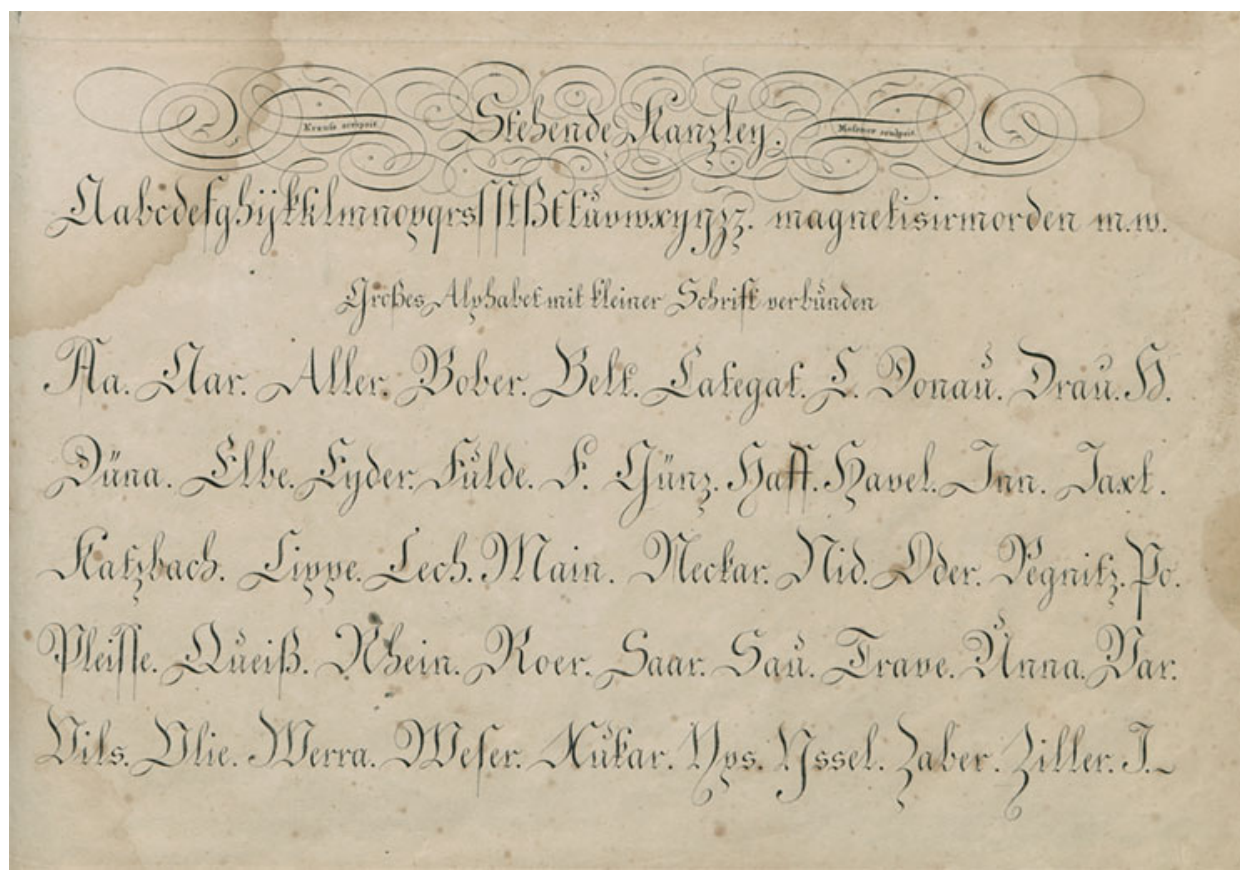

Figure 3: 'Calligraphy containing the word "magnetisirmorden" [murder by magnetisation]'. F. Krauß, Englische und Deutsche Vorschriften (1822), fol. 6r, Staatsbibliothek zu Berlin - Preußischer Kulturbesitz (Sig. 50 MA 22606).

hand and recommendation letters. ${ }^{66}$ Krauß recounted that he made these expensive copper engravings in 1820/21, sold 200 copies and displayed them in an art exhibition in Stuttgart in 1824 . He referred to calligraphy as 'the only talent not ruined by the magnetisers' ${ }^{67}$ Interestingly enough, the words 'Magnetismus' (Magnetism) and 'magnetisirmorden' (murder by magnetisation) appear on two of the sheets. ${ }^{68}$ These are the first textual traces that testify to his characteristic fears (Figure 3).

From the 1820s onwards Krauß worked as a salesman, travelling the southern and western regions of Germany. He consulted doctors and 'counter magnetisers' throughout Europe. ${ }^{69}$ In 1827, for instance, the Paris-based founder of phrenology, Franz Joseph Gall (1758-1828) is said to have examined his skull but allegedly did not comment on the issue of Mesmerism. ${ }^{70}$ That same year Krauß was even granted an audience by the Dutch king. He kept a Diarium der Peinigungen [Diary of Torments] spanning the years 1832-35; in 1836 he engaged in correspondence with C. L'Hermet, an alleged fellow sufferer from Magdeburg, ${ }^{71}$ and in 1836 and 1837 he published two shorter apologetic writings in

\footnotetext{
${ }^{66}$ For details, see Burkhart Brückner and Ferenc Jádi, 'Friedrich Krauß als Kalligraph: Ein psychodynamischer und produktionsästhetischer Blick auf den Verfasser des Nothschrei eines Magnetisch-Vergifteten und sein Werk', Schriftenreihe der Deutschen Gesellschaft für Geschichte der Nervenheilkunde, 18 (2012), 313-40.

${ }^{67} \mathrm{Krau}$, op. cit. (note 1), $46 \mathrm{f}$.

${ }^{68} \mathrm{Krau}$, op. cit. (note 65), fol. 6r, fol. $12 \mathrm{r}$.

${ }^{69} \mathrm{Krau}$, op. cit. (note 1), 16-29; Krauß, op. cit. (note 2), 5 f.

${ }^{70} \mathrm{Krau}$, op. cit. (note 1), 9, 138, 288.

${ }^{71}$ Ibid., 62-91.
} 
French. ${ }^{72}$ In 1838 he sent letters to Christian Friedrich Nasse in Bonn. ${ }^{73}$ Between April and August of 1843, Krauß used the Heidelberg residence of the physician Maximilian Joseph von Chelius (1794-1876) as his mailing address. ${ }^{74}$ During the 1840 s he toured Germany's entire north-western region, with only passing reference made to the beginning of the 1848 March Revolution in Baden. ${ }^{75}$ In 1849 he published a second portfolio of calligraphies entitled Vorlegeblaetter von Englischen Schriftzügen \& Fractur [Style Sheets for English Lettering \& Fraktur]. ${ }^{76}$ His Nothschrei appeared in 1852. Krauß reduced his professional activities in the mid-1860s and issued his sixth, 380-page publication, Nothgedrungene Fortsetzung meines Nothschrei [Forced Continuation of My Cry of Distress], in 1867. Friedrich Krauß died in Stuttgart shortly thereafter, in November 1868, at the age of 77.

\section{Nothschrei and Patient Experience}

Krauß's writings belong to a particular subset of nineteenth-century narratives whose authors rejected interpretations suggesting that they were mad, yet still sought professional help. This ambivalent attitude distinguishes these texts from personal narratives written by individuals who completely withdrew from their social environments, but also from those writings whose authors either successfully co-operated with psychiatrists or found their own productive ways of handling their experiences without adopting any psychiatric interpretations. $^{77}$

Throughout the text, language serves as both a safe haven and a weapon. Krauß employs multiple languages and dialects, interspersing verses and an ornate grammar with considerable rhetorical skill. ${ }^{78}$ The narrative here serves not only to generate meaning but also provides a protective mask (for, as Krauß put it, 'Where there is pain, the words also vibrate...'). ${ }^{79}$ The text is presented as entirely self-sustaining; the lengthy title already seems to tell the whole story. This autopoietic and recursive structure has two opposite effects. On the one hand, Krauß produces a plethora of repetitive, seemingly rational arguments to prove the events described - with the sole purpose of justifying himself and lecturing his audience. He thus claims an expert position. On the other hand, this constant repetition conceals the fact that he tells the reader very little about his actual everyday life.

Krauß expressed his experiences and his suffering in a straightforward manner. He incessantly described agonising sensations of heat induced by 'concentrated fiery gases'

\footnotetext{
${ }^{72}$ Friedrich Krauß, Appel du sieur Frédéric Krauss contre des influences magnétiques auxquelles il se croit en butte (Paris: Bellemain, 1836). Friedrich Krauß, Lettre de M. Frédéric Krauss sur le magnétisme et sur l'influence de certains magnétiseurs conjurés contre lui (Paris: Herhan et Bimont, 1837). Nothschrei includes German versions of both texts.

${ }^{73}$ Krauß, op. cit. (note 1), VN 69, 274.

${ }^{74}$ Ibid., 302, 322.

75 Ibid., 673, 684.

${ }^{76}$ Friedrich Krauß, Vorlegeblaetter von Englischen Schriftzügen \& Fractur in grösserem Masstabe zur gründlichen Einsichtnahme der Formen und Arten (Stuttgart, 1849). For details, see Brückner and Jádi, op. cit. (note 66), 323. One existing copy in Württembergische Landesbibliothek (Stuttgart; 27 sheets, $47 \times 29 \mathrm{~cm}$ ).

77 On this typology, see Brückner, op. cit. (note 11), 178-86.

78 On Krauß's use of language, see Christine Wunnicke, “'Auserwählt zum Aufbrauch”, - Der bürgerliche Wahnsinn des Friedrich Krauß', in Hahn, Person and Pethes, op. cit. (note 1), 110-24; Stefan Rieger, 'Psychopaths electrified - Die Wahnwege des Wissens im Nothschrei eines Magnetisch-Vergifteten', in Hahn, Person and Pethes, op. cit. (note 1), 151-72.

${ }^{79} \mathrm{Krau}$, op. cit. (note 1), VN 41.
} 
entering his body, mainly through his ears. ${ }^{80}$ An illustrative case in point is a diary entry of 10 October 1864:

Because I am already in bed by 1 o'clock, the murderous morons are happily looking forward to a merry night. Raid-like, blazing heat is driven up from the foot soles and these frissons of heat keep coming all night long with only few interruptions; whenever a new load of fire came on, I had to stretch away from that spot up to where they had advanced; thus starting from the legs, then on from the lower back and spine, finally from the chest; as soon as the fumes are driven further up and the blaze has been stoked anew, sweat breaks out from that spot. When the day broke, these gentlemen, finally satiated, took rest from the orgy, and after the fluid mass had evaporated bit by bit, I fell asleep from tiredness and exhaustion. . . ${ }^{81}$

He also complained about a permanent headache, cough, inflammations, heartburn and toothaches, and kept meticulous notes of his enemies' imaginary comments. ${ }^{82}$ In his mind, this 'gang' was omnipresent:

They always keep track of my thoughts, besiege my ideas, seek to influence them and are on guard like a cat watching a mouse.... They use my thoughts, persecute them, deride them, thereby stoke their rage so that they can properly enjoy it, and punish me with increased smouldering. ${ }^{83}$

Krauß felt that the most agonising assaults always occurred at night.

These rippers have their magnetising apparatus in my bed or next to it, else they could not coil along con amore at their fancy and pleasure, and further drive in the ether. . ${ }^{84}$

Elsewhere, he explained that his gaze was made to turn 'lecherous' as soon as he was 'friendly to a girl'. Only on rare occasions did the events involve pleasure; for instance, when he felt 'propelled by magnetism', which allegedly gave him the impression of dancing in the air with joy. ${ }^{85}$ But his feelings were usually dominated by pain, fear and anger. He referred to his tormentors as 'vampires', 'monsters', 'anthropophagists' and 'hottentots', whose sole goal was to drive him mad. ${ }^{86}$

A recurrent theme in these writings is the perceived destruction of the author's sense of self. Krauß felt like an 'automaton' with a 'goddamned pseudo-life' ${ }^{87} \mathrm{He}$ employed a number of strategies to counter this phenomenon. One was to plug his ears, swear and pray aloud, put his feet in cold water and anoint his body in order to soothe these agonising sensations. ${ }^{88}$ Another means for him to retain his sense of autonomy was to ensure that he always earned his own living. Nineteenth-century travelling salesmen like Krauß played an active part in the emergence of modern markets, ${ }^{89}$ and he explicitly distanced himself from the working class. ${ }^{90}$ Calligraphy provided a further source of income. In an advertisement included in Nothschrei, he proclaimed his 1849 portfolio Vorlegeblaetter to be an educational tool by which pupils can grasp 'the idea of beauty' embedded in a plain

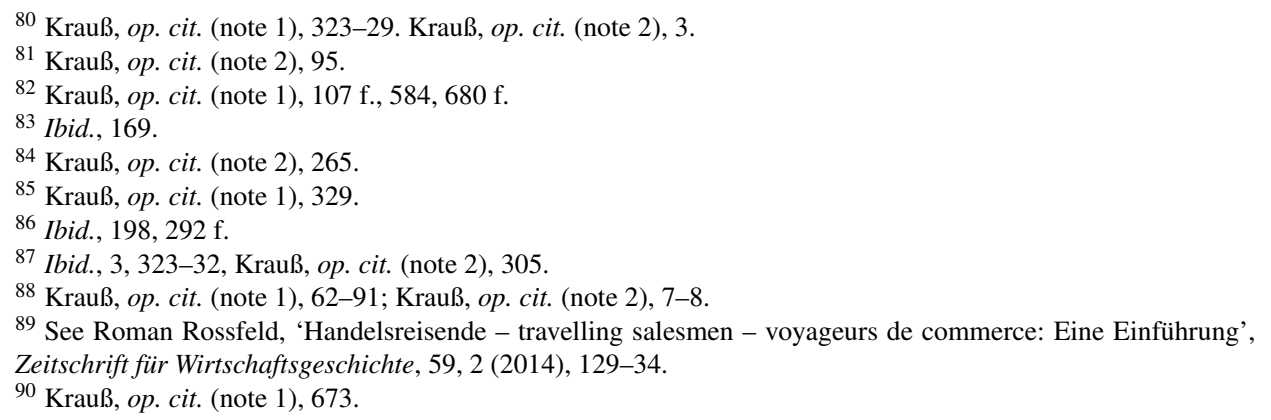


and simple design. ${ }^{91}$ Altogether, his earnings were sufficient to become a silent partner in a Stuttgart-based manufacturing business (in which he lost several thousand guilders during the 1860 s). ${ }^{92}$

In addition, Krauß insisted on his individual and human rights, and invoked the rule of law by filing numerous petitions. Torsten Hahn has reconstructed the discursive line along which Krauß tried to explain why the state authorities failed him: it must be a feudal system where criminal sanctions are at the discretion of the powers that be. ${ }^{93}$ The imaginary voice of the van Asten father got straight to the point: 'You are a democrat, they won't listen to you. ${ }^{94} \mathrm{Krau} ß$ shared his frustration and scepticism about the bureaucratic authoritarian state with all democratically oriented citizens in pre-1848 Germany. The bourgeois public sphere provided him with a platform to channel his thinking.

Finally, Krauß's Protestant faith gave him stability and helped him maintain his sense of selfhood. ${ }^{95}$ For instance, his entry on Christmas Day, 1849 attests to this:

In Church, the barrel organ and plainchant always stirred such emotion in me that I just had to restrain myself and keep my hotly swollen lips closed, so that I did not sob loudly and weep and constantly wipe my eyes. ${ }^{96}$

Here, religion fulfilled its purpose as a mediator between individual suffering and collective cultural meaning. It is only towards the end of Nothschrei that we find the desperate exclamation, 'God has turned to filth!'97

In sum, Krauß presented himself as both a victim and a fighter. The victim sought help, while the fighter sought to keep the helpers at a distance. This ambivalence is typical of his narrative as well as of his attitude towards Mesmerism. While ignoring the controversies on 'animal magnetism' among the expert public, Krauß nonetheless argued within the framework of socially accepted patterns of interpretation. Just as the theory of animal magnetism provided its audience with a tool to enact and negotiate social relations, it also helped Krauß come to terms with the challenges in his life.

\section{Historiographical Reflections}

Friedrich Krauß never saw himself as being mentally disturbed. In 1867, he wrote:

[T]his is a condition that does not belong to the realm of idées fixes, of illusions and hallucinations, of phantasies. . This is all about protecting a persecuted citizen by diplomatic means, thereby putting an end to these body and soul killers and their shameful doing. ${ }^{98}$

In 1861, when Krauß was still alive, renowned psychiatrist Wilhelm Griesinger (18171868) referred to him in his textbook as a case of 'partial madness' with 'systematically developed and dramatised delusions of physical and mental interference'. According to Griesinger, the 'sensitive anomalies' were often hidden and, in the case of 'hypochondria', were not accompanied by any mental disorder. ${ }^{99}$ This more modern concept clearly

91 Ibid., inserted after p. 913.

92 Krauß, op. cit. (note 2), 371.

93 Cf. Torsten Hahn, 'Government denies knowledge - Friedrich Krauß' Verschwörungstheorie und die Grenzen des Rechts', in Hahn, Person and Pethes, op. cit. (note 1), 201.

94 Krauß, op. cit. (note 1), 749.

95 Ibid., 230.

96 Ibid., 749; entry of 25 December 1849; cf. 575.

97 Ibid., 879.

${ }^{98} \mathrm{Krau}$, op. cit. (note 2), 1.

${ }_{99}$ Wilhelm Griesinger, Die Pathologie und Therapie der psychischen Krankheiten für Aerzte und Studirende, 2nd edn (Stuttgart: Krabbe, 1861), 345. Griesinger also cited James Tilly Matthews (op. cit., note 12). 
differentiated between underlying disorder and symptoms. By then, the mesmerist element had become insignificant - what prevailed was Justinus Kerner's clinical perspective with its pessimistic prognosis but favourable assessment of Krauß's psychosocial functioning.

In the second half of the nineteenth century, German psychiatry increased its focus on neuropathology and nosological innovations. The discipline became institutionalised and the asylum system was expanded. ${ }^{100}$ There seems to be no reference to Krauß in the growing body of literature on 'hypnotism', although cases similar to his were mentioned. ${ }^{101}$ Nothschrei was briefly cited in 1895 by Albert Behr, who discussed 'the issue of paranoia' in the context of degeneration theory. ${ }^{102}$ In 1912, Bernhard Beyer quoted several paragraphs in his criticism of the radical liberal protest movement against the European asylum system between 1880 and 1920, to which Nothschrei could be considered a literary precursor. ${ }^{103}$ Krauß's book was overlooked by both psychoanalysts and proponents of phenomenological psychiatry.

It was not until 1967 that Krauß's case was reconstructed in detail. The Göttingen psychiatrists Heinz Ahlenstiel and Joachim-Ernst Meyer conducted a biographical analysis and concluded:

Friedrich Krauß appears as a human being who is suffering and passionately defending himself. ... He perceives the alter ego, his tormentors, simply as evil and devilish people, which is why he reports on fifty years of suffering in such a vivid, unreflected and very human manner.' 104

They ultimately diagnosed him with 'psychosis, paranoia, hallucinations' and called the book one of the 'great self-portrayals of a schizophrenic mind'. Krauß's experiences of influence were apparently rated as typical 'first-rank symptoms of schizophrenia' in the tradition of psychiatrist Kurt Schneider. ${ }^{105}$

Another thirty-five years later, adopting a more historical approach, four contributions to the 2002 edited volume Grenzgänge zwischen Wahn und Wissen [Crossing the Boundaries between Madness and Knowledge] re-established the link with Mesmerism in their discourse analyses of Nothschrei. ${ }^{106}$ Despite once again employing retroactive diagnoses ('psychosis with acute phases', 107 'paranoia', ${ }^{108}$ 'paranoid schizophrenia' ${ }^{109}$ ), the editors point out that the content of Krauß's experience - the alleged 'magnetisation' through technical devices - reflected an increasingly rationalised and mechanised society, characteristic of the early nineteenth-century experimental sciences: 'What is now, in retrospect, seen as textually manifest signs of paranoia was presented [in Nothschrei] as

\footnotetext{
${ }^{100}$ See Eric J. Engstrom, Clinical Psychiatry in Imperial Germany (Ithaca, NY: Cornell University Press, 2003).

101 See Auguste Forel, Der Hypnotismus (Stuttgart: Enke, 1895), 136. Albert Moll, Hypnotism, 4th edn (London: Scott, 1897), 329.

102 Albert Behr, 'Über die schriftstellerische Thätigkeit im Verlaufe der Paranoia', Sammlung klinischer Vorträge, 134 (1895), 375. On the 'issue of paranoia', see Brückner, op. cit. (note 11), 100-31.

103 Bernhard Beyer, Die Bestrebungen zur Reform des Irrenwesens (Halle: Marhold, 1912), 155-61. On this movement, see Brückner, op. cit. (note 11), 161-77.

104 Ahlenstiel and Meyer, op. cit. (note 3), 29. Cf. Harald Feldman, 'Die magisch-mythischen Wahngedanken Schizophrener: Teil II', Confinia Psychiatrica 9 (1966), 79-92.

105 Kurt Schneider, Klinische Psychopathologie, 8th edn (Stuttgart: Thieme, 1967). Leonhard diagnosed Krauß's condition as a 'hypochondriac paraphrenia and severe chronic schizophrenia', Karl Leonhard, 'Schizophrene mit typischen Defektzuständen nach ihren eigenen Schriftstücken', Archiv für Psychiatrie und Nervenkrankheiten und Zeitschrift für die gesamte Neurologie und Psychiatrie, 211, 1 (1968), 9-14.

${ }^{106}$ Nothschrei was listed by Adam Crabtree, Animal Magnetism, Early Hypnotism, and Psychical Research, 1766-1925: An Annotated Bibliography (White Plains, NY: Kraus, 1988), 165, 218.

${ }^{107}$ Hahn, op. cit. (note 93), 193.

108 Rieger, op. cit. (note 78), 153.

109 Wunnicke, op. cit. (note 78), 112.
} 
objective and quantifiable knowledge. ${ }^{110}$ More recently, in 2007, further research focused on the biographical events that triggered Krauß's 1814 crisis and led to the discovery of his calligraphic work. This corpus was thoroughly examined in 2012 by this author, who also included a critical assessment of the aforementioned retroactive diagnoses. ${ }^{111}$

Friedrich Krauß's story, then, has remained fairly little known amongst historians. This is certainly the case compared to more illustrious first-person accounts, such as that of Daniel Paul Schreber, which was popularised by Sigmund Freud; ${ }^{112}$ but also - indeed especially - in the English-speaking community. ${ }^{113}$ This is particularly noteworthy in view of the book's length: Nothschrei is unusually voluminous in relation to the case histories typically presented in standard psychiatric textbooks at that period (a fact not unrelated, of course, to Krauß's full liberty as a self-published author). Finally, it is also interesting to note that although his case was 're-discovered' during a time of profound criticism of psychiatry and of the very validity of the schizophrenia diagnosis, Krauß has not - at least to this author's knowledge - been the subject of commentary in studies taking this particular stance. ${ }^{114}$

\section{Conclusion}

This study has focused on the story of Friedrich Krauß from both a historical and historiographical perspective. It has also offered new insights into Krauß's medical treatment - especially at the Antwerp asylum, something that has not previously been explored - and the reception of his case. However, the work of Friedrich Krauß is still far from having been exhaustively researched. A more detailed historical and historiographical comparison between his and more famous accounts (eg. James Tilly Matthews and Daniel Paul Schreber) would undoubtedly shed new light on his story, as would a more literary approach focused on the aesthetics of his work.

According to Roy Porter, 'language, history and culture' 115 are the points of reference in examining first-person accounts. In Krauß's case, we have to consider the author's specific relationship with the historical context in which he acted. Neither his biography nor the structure of Nothschrei can be understood without acknowledging the role of Mesmerism in nineteenth-century Germany. Multi-faceted and diverse, this theory provided Krauß with a concept that was socially accepted but sufficiently ambivalent to allow for an interpretation in line with his own purposes. He selectively appropriated and adapted mesmerist elements to make sense of his personal issues. Yet he also sought help from doctors. In this respect, the story of Friedrich Krauß illuminates the constant interaction between a layman and the broader medical and extra-medical community at this period. Fighting for recognition, he courted the expert public; but in so doing he achieved the

\footnotetext{
${ }^{110}$ Hahn, Person and Pethes, op. cit. (note 1), 8. Cf. Thomas Fuchs, 'Being a psychomachine: On the phenomenology of the influencing-machine', in Thomas Röske and Bettina Brand-Claussen (eds), The Air-loom and Other Dangerous Influencing Machines (Heidelberg: Wunderhorn, 2006), 27-43.

111 See Brückner, op. cit. (note 11), 236-57; Brückner and Jádi, op. cit. (note 66).

112 Sigmund Freud, 'Psychoanalytische Bemerkungen über einen autobiographisch beschriebenen Fall von Paranoia (Dementia paranoides)', in Sigmund Freud, Gesammelte Werke, Vol. VIII (London: Imago, 1943), 240-320. Psychodynamic views on Krauß are discussed in, Brückner and Jádi, op. cit. (note 66).

113 The case was first presented to an English-language audience in a brief review of Ahlenstiel and Meyers's 1967 publication on Krauß, see Erwin Engel, 'Selbstschilderungen eines Geisteskranken', review, British Journal of Psychiatry 113, 502 (1967), 1051-52. Cf. the recent brief discussions on Krauß in, Steven Connor, The Matter of Air: Science and Art of the Ethereal (London: Reaktion, 2010), 87-91; Joel Gold and Ian Gold, Suspicious Minds: How Culture Shapes Madness (New York: Free Press, 2014), 67-70.

114 See Norman Dain, 'Psychiatry and antipsychiatry', in Mark S. Micale and Roy Porter (eds), Discovering the History of Psychiatry (New York: Oxford University Press, 1994), 415-44.

115 Porter, op. cit. (note 5), 2.
} 
exact opposite: at the end of his life, he was deemed an exemplary psychiatric case. These interactions between doctors and patients, between the views 'from above' and 'from below', cannot be interpreted in terms of a strict dichotomy, as the individuals are embedded within a cultural network that dynamically shapes representations of self, illness and identity.

On the other hand, Kerner's and Kieser's cautious but unequivocal statements regarding Krauß's condition highlight the fluid boundaries between mesmerist and more orthodox forms of psychiatric thinking. Both physicians applied mesmerist knowledge and clinical categories simultaneously but in practice they preferred the latter - and it was this 'clinical gaze' on Krauß that prevailed over two hundred years. Deconstructing the dominance of this clinical gaze can therefore play an important - and source-appropriate - role in reconstructing the history of psychiatry 'from below'. From this perspective, Nothschrei is only one example of the long tradition of personal narratives of madness, asylums, social deviation and psychiatry which ought to be acknowledged as a bona fide genre by historians of psychiatry and literature alike. 